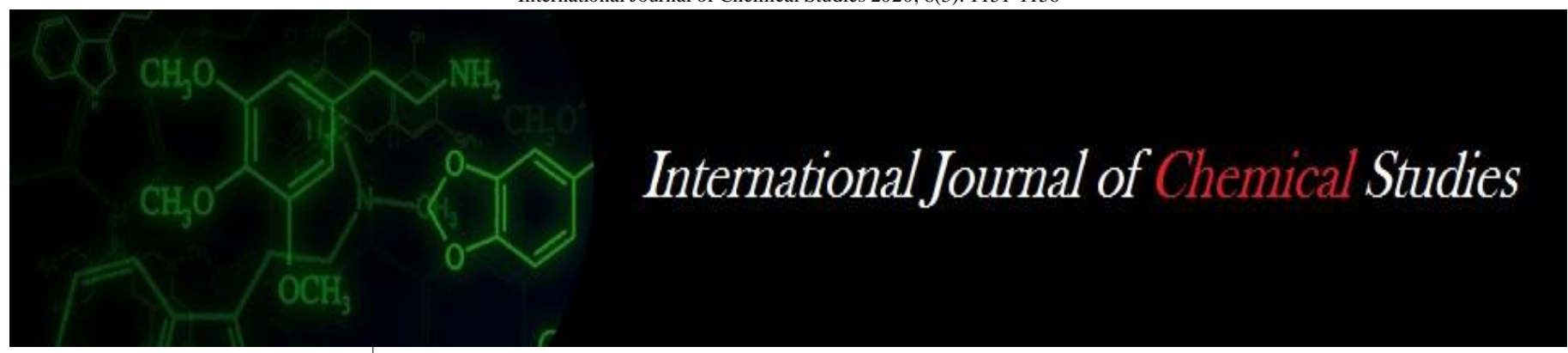

P-ISSN: 2349-8528

E-ISSN: 2321-4902

www.chemijournal.com

IJCS 2020; 8(3): 1151-1156

(C) 2020 IJCS

Received: 16-03-2020

Accepted: 18-04-2020

\section{Subhash Bhanwar}

M.Sc. (Ag) Agronomy, Dr. B.R.

Ambedkar University of Social

Sciences, Mhow, Madhya

Pradesh, India

Gabu Singh Gathiye

Scientist (Agronomy),

RVSKVV-Krishi Vigyan

Kendra, Dhar, Madhya Pradesh,

India

Vishal Verma

JRF, Division of Genetics and

Plant propagation, TFRI,

Jabalpur, Madhya Pradesh,

India

\section{Effect of herbicides on growth, yield and economics in soybean (Glycine max $\mathrm{L}$.)}

\author{
Subhash Bhanwar, Gabu Singh Gathiye and Vishal Verma
}

DOI: https://doi.org/10.22271/chemi.2020.v8.i30.9355

\begin{abstract}
An experiment entitled "Effect of Herbicides on Growth, Yield and Economics in Soybean (Glycine max L.)" was conducted in Kharif season 2015 at research farm of BRAUSS, MHOW, (M.P.). The soil of the experimental field was medium black in texture, neutral in reaction $(\mathrm{pH} 7.60)$ with normal EC (0.45 $\mathrm{dS} / \mathrm{m})$ and medium organic carbon contents $(0.72 \%)$ and analysing low in available $\mathrm{N}(270 \mathrm{~kg} / \mathrm{ha})$, medium in available P $(6.9 \mathrm{~kg} / \mathrm{ha})$ and high in available $\mathrm{K}(382 \mathrm{~kg} / \mathrm{ha})$ contents. Due to dominance of montmorillonite clay content it has high capacity to swell and shrink and high CEC. A field experiment was consisted of 9 treatments replicated four times in randomized block design (RBD). As per treatment, the seed of soybean $c v$. JS 335 was sown in all the treatments consisting with pre and post emergence herbicides. The maximum number of pods (30.90) and seed weight $(11.10 \mathrm{~g})$ was recorded under treatment $\mathrm{T}_{9}$-weed free plot followed by $\mathrm{T}_{4}$-fenoxaprop-p-ethyl, which gave the value of 27.60 pods/plant and $11.0 \mathrm{~g}$ seed index. The lowest number of pods (26.60) and seed index (9.20) was recorded under treatment $\mathrm{T}_{8}$-control. The highest grain and stover yield (14.33 and $\left.15.52 \mathrm{q} / \mathrm{ha}\right)$ was recorded under treatment $\mathrm{T}_{9}$-weed free plot followed by (14.0 and $14.73 \mathrm{q} / \mathrm{ha}$ ) under treatment $\mathrm{T}_{4}$-fenoxaprop-p-ethyl $9 \%$ EC while lowest grain and stover yield $\left(9.14\right.$ and $11.38 \mathrm{q} / \mathrm{ha}$ ) was obtained under treatment $\mathrm{T}_{8}$ (control). The highest net return (Rs.32796/ha) was obtained under the treatment $\mathrm{T}_{9}$ (weed free situation) closely followed by $\mathrm{T}_{4}$ fenoxaprop-p-ethyl 9\% EC (Rs.32359/ha) while the lowest net return (Rs.18284/ha) was received under the treatment $\mathrm{T}_{8}$ (control). The highest benefit: cost ratio (2.30) was obtained under the treatment $\mathrm{T}_{4}$-Fenoxaprop-p-ethyl 9\% EC closely followed by $\mathrm{T}_{3}$-Chlolrimuron-ethyl 25\% WP (2.29) and $\mathrm{T}_{9}$ (weed free situation) (2.20) while the lowest benefit:cost ratio (1.45) was received under the treatment $\mathrm{T}_{8}$ (control).
\end{abstract}

Keywords: Soybean, pre and post emergence herbicide, yield and economics

\section{Introduction}

Soybean (Glycine $\max (\mathrm{L})$ Merrill) is established as one of the major monsoon season field crops in Malwa plateau of Madhya Pradesh. It has become a economical crop because of comparatively good economic return/unit area obtained by the farmers from its improvement in the living condition of farmers. Indian soybean holds on an average $37-41 \%$ protein, 17 $21 \%$ oil, $25-30 \%$ carbohydrate, $4-5 \%$ ash, $4-5 \%$ crude fibre and $2 \%$ phospholipids, Hence, it is called ''meat of the field'. It has recorded biological value of 2.5 and 3.5 PER (protein efficiency ratio) when it is used as raw and processed respectively. However, its productivity in the State id $1102 \mathrm{~kg}$ ha- 1 which is very low as compared to the global productivity of 2206 $\mathrm{kg} / \mathrm{ha}$ (Anonymous, 2014) ${ }^{[1]}$.

Among the causes of low productivity, weeds are the major problems causing about $37 \%$ yield reduction. Weed control is indispensable in modern crop management because weeds cause competitional stresses for light, moisture, space, nutrients and may have some allelopathic as well, resulting in poor crop growth especially during the 40 days after sowing and thereby yields are reduced markedly (Tiwari et al., 1997) ${ }^{[18]}$. Complete mechanical and/or manual weeding may not be possible and cost effective during the critical period of crop weed competition for obvious reasons.

Pre and post-emergence herbicides are considered almost synonymous with modern weed science technology, as they gave a new direction to the formers to get the maximum yield potential of the crop at lower cost of production. Areas where farmers are progressive and have greater managerial ability, with scarcity of labour, chemical weed control has emerged out as one of the important factors in increasing the yield of crop. The medium to deep Vertisol soils
Gabu Singh Gathiye

Scientist (Agronomy),

RVSKVV-Krishi Vigyan

Kendra, Dhar, Madhya Pradesh,

India 
in Malwa plateau in monsoon season at times lose their workability due to rains and mechanical weeding in standing crop becomes almost impossible. Under such situations, the chemical weed control seems to be the best option to overcome the weed competition and get higher yield.

\section{Material and methods}

The experiment was conducted on the Research Farm of BRAUSS Mhow in Rehati Hoshangabad, (M.P.). The topography of the experimental area are fairly leveled and proper drainage was provided. The plots were protected as not to allow the free flowing of surface runoff water, affecting the individual plot treatments. The meteorological data showed that the total rainfall received during the crop growth period was $588 \mathrm{~mm}$. The maximum temperature varied from 25.7$32.6^{\circ} \mathrm{c}$ and the minimum temperature varied from $14.1-23.2^{\circ} \mathrm{c}$. The total number of rainy days was 28. Soil temperatures varied from $21.0-27.2^{\circ} \mathrm{c}$.

The soil of the experimental field has been grouped under medium black (Vertisols) belonging to fine montmorillonite hypertharmic family predominantly clay textural class. For fertility status of the experimental area, the soil samples were collected randomly with the help of soil augar before sowing from the experimental field and representative composite sample was made for the mechanical and chemical analysis.

\section{Chemical analysis of experimental soil}

\begin{tabular}{|c|c|c|c|}
\hline Analysis & Quantity & Category & Method adopted \\
\hline Soil pH & 7.6 & Slightly & Glass electrode method (pH meter) (Jackson, 1967) ${ }^{[6]}$ \\
\hline Electrical conductivity $\left(\mathrm{dSm}^{-1}\right)$ & 0.45 & Normal & Conductivity meter at $25^{\circ} \mathrm{C}$ (Jackson, 1967) ${ }^{[6]}$ \\
\hline Organic carbon $(\%)$ & 0.72 & Medium & Walkley and Black's rapid titration method \\
\hline Available nitrogen $(\mathrm{kg} / \mathrm{ha})$ & 270 & Medium & Alkaline permanganate method (Jackson, 1967) ${ }^{[6]}$ \\
\hline Available phosphorus (kg/ha) & 6.9 & Low & Olsen’s (Jackson, 1967) ${ }^{[6]}$ \\
\hline Available potash (kg/ha) & 382 & Medium & Flame photometer (Jackson, 1967) ${ }^{[6]}$ \\
\hline
\end{tabular}

The experiment consisting of nine treatments and four replications with randomized block design was laid out in the experiment. Alachlor, Pendimethalin are the herbicides, which were used as pre emergence. These were sprayed immediately after the sowing of soybean crop. Chlorimuron ethyl, fenoxoprop ethyl, Chlorimuron ethyl + fenoxoprop ethyl, quizaifop ethyl, and imazethapyr were used as post emergence herbicide. These were sprayed at 15-25 days after planting as per herbicide. The herbicides spray mixture was added with $1 \mathrm{ml}$ per litre of gum as stickers. The following observations were recorded under the study:

\section{Number of pods per plant}

Number of pods counted on 10 already tagged sample plants per plot and mean was calculated,

\section{Seed Index (g)}

100 grains was counted from the seed sample taken from finally cleaned produce of each plot for recording test weight. The weight of 100-seed was recorded on a electrical balance.

\section{Seed yield (q/ha)}

The seed yield per net plot was recorded after drying the seed it is also known as economical yield. The plot yield was later on converted in to quintal per hectare by multiplying it by conversion factor.

\section{Stover yield (q/ha)}

The stover yield per plot was obtained by subtracting grain yield (economical yield) from biological yield (bundle weight) in each plot. This was later on converted in to $q /$ ha.

\section{Harvest index}

It is the ratio of economic yield to the biological yield. In case of legumes, it is the ratio of grains to the total dry matter and expressed in percentage as follows:

$$
\text { Harvest index (\%) }=\frac{\text { Economic yield (grain yield) }}{\text { Biological yield }} \times 100
$$

Economics

Economic analysis of input and yields made. Cost of labour, fertilizer, herbicide and insecticide and other inputs required during growing of the crop were noted and gross profit, net profit and cost: benefit ratio of each treatment were noted and gross profit, net profit and cost: benefit ratio of each treatment were calculated on the basis of the prevailing market rates of the items of inputs and the price of the commodity produced.

\section{Results and discussion \\ Growth parameters \\ Plant height (mm)}

Data revealed that average plant height increased progressively with increase in the age of the crop till 75 DAS. The plant gained height at increased rate between 30 to 45 DAS and relatively slower rate between 60 and 75 DAS.

It is evident from the data presented in Table 1, that two preemergence herbicide treatment i.e. alachlor $50 \mathrm{EC} @ 2$ litre a.i./ha $\left(\mathrm{T}_{1}\right)$ and pendimethalin $30 \mathrm{EC} @ 750 \mathrm{ml}$ a.i./ha $\left(\mathrm{T}_{2}\right)$ and post emergence herbicide i.e quizalofop-ethyl 5\% EC @ $50 \mathrm{ml}$ a.i./ha $\left(\mathrm{T}_{6}\right)$ and Imazethapyr 5\% SL @ $75 \mathrm{mI}$ a.i./ha $\left(\mathrm{T}_{7}\right)$ gave relatively shorter plant height at all the stages of crop growth as compared to that in treatment $\mathrm{T}_{9}$ (weed free). Maximum plant height of $574 \mathrm{~mm}$ at harvest was recorded in treatment of weed free condition $\left(\mathrm{T}_{9}\right)$ and closely followed by $\mathrm{T}_{4}$ (Fenoxaprop-p-ethyl) $564 \mathrm{~mm}, \mathrm{~T}_{5}$ (Chlorimuron-ethyl + Fenoxaprop-p-ethyl) $562 \mathrm{~mm}$ and $\mathrm{T}_{3}$ (Chlorimuron-ethyl) 561 $\mathrm{mm}$, suggesting that these chemicals could be used for weed control in soybean. 
Table 1: Average plant height as influenced by different treatments at successive stages of plant growth

\begin{tabular}{|c|c|c|c|c|c|c|}
\hline \multirow{2}{*}{ Tr. No. } & \multirow{2}{*}{ Treatments } & \multicolumn{5}{|c|}{ Plant height $(\mathrm{mm})$} \\
\hline & & 30 DAS & 45 DAS & 60 DAS & 75 DAS & At harvest \\
\hline $\mathrm{T}_{1}$ & Alachlor $50 \mathrm{EC}, 2.0 \mathrm{~kg} / \mathrm{ha}$ (Pre.eme.) & 118 & 375 & 533 & 531 & 525 \\
\hline $\mathrm{T}_{2}$ & Pendimethalin 30 EC, 750 g/ha (Pre.eme.) & 119 & 373 & 527 & 532 & 531 \\
\hline $\mathrm{T}_{3}$ & Chlorimuron-ethyl 25\% WP, $9.37 \mathrm{~g} / \mathrm{ha}$, post eme. (20 DAS) & 150 & 377 & 566 & 574 & 561 \\
\hline $\mathrm{T}_{4}$ & Fenoxaprop-p-ethyl 9\% EC, $67.5 \mathrm{~g} / \mathrm{ha}$ post eme.(20 DAS) & 156 & 392 & 587 & 590 & 564 \\
\hline $\mathrm{T}_{5}$ & Chlorimuron ethyl + Fenoxaprop-ethyl, $9.37 \mathrm{~g} / \mathrm{ha}+67.5 \mathrm{~g} / \mathrm{ha}$, post eme. & 156 & 381 & 585 & 581 & 562 \\
\hline $\mathrm{T}_{6}$ & Quizalafop-p-ethyl 5\% EC, $50 \mathrm{~g} / \mathrm{ha}$, post eme. (15 DAS) & 114 & 368 & 493 & 493 & 512 \\
\hline $\mathrm{T}_{7}$ & Imazethapyr 5\% EC, $50 \mathrm{~g} / \mathrm{ha}$, post eme. (25 DAS) & 112 & 360 & 483 & 486 & 521 \\
\hline $\mathrm{T}_{8}$ & Control (unweeded) & 90.6 & 323 & 461 & 466 & 496 \\
\hline $\mathrm{T}_{9}$ & Weed free & 161 & 415 & 598 & 601 & 574 \\
\hline & SEm & 10 & 11.7 & 21.7 & 18.9 & 11.2 \\
\hline & $\mathrm{CD}$ at $5 \%$ & 29.3 & 34.4 & 63.5 & 55.3 & 32.7 \\
\hline
\end{tabular}

\section{Number of branches per plant}

The average number of branches/plant increased with the increase in the age of the crop. The maximum number of branches/plant was recorded in the treatment $\mathrm{T}_{9}$ (weed free plot) at all the stages of crop growth followed by $\mathrm{T}_{4}$ fenoxaprop-ethyl $9 \%$ EC, which was applied as postemergence herbicide at 20 DAS. It was significant to record that the values of number of branches/plant (3.38 and 3.12) were almost same at 75 DAS and at harvest, since no branching function took place after 75 DAS. The treatment $\mathrm{T}_{6}$ (quizalofop-p-ethyl 5\% EC) and $\mathrm{T}_{7}$ (Imazethapyr 5\% SL) were almost similar in influencing the number of branches/plant at all stages of plant growth.

Table 2: Effect of different treatments on average number of branches per plant

\begin{tabular}{|c|c|c|c|c|c|c|}
\hline \multirow{2}{*}{ Tr. No } & \multirow{2}{*}{ Treatments } & \multicolumn{5}{|c|}{ Average number of branches/plant } \\
\hline & & 30 DAS & 45 DAS & 60 DAS & 75 DAS & At harvest \\
\hline $\mathrm{T}_{1}$ & Alachlor $50 \mathrm{EC}, 2.0 \mathrm{~kg} / \mathrm{ha}$ (Pre.eme.) & 0.70 & 1.60 & 2.25 & 2.28 & 2.24 \\
\hline $\mathrm{T}_{2}$ & Pendimethalin 30 EC, $750 \mathrm{~g} / \mathrm{ha}$ (Pre.eme.) & 0.73 & 1.48 & 2.10 & 2.10 & 2.03 \\
\hline $\mathrm{T}_{3}$ & Chlorimuron-ethyl 25\% WP, 9.37 g/ha, post eme. (20 DAS) & 0.90 & 1.69 & 2.80 & 2.80 & 2.78 \\
\hline $\mathrm{T}_{4}$ & Fenoxaprop-p-ethyl 9\% EC, $67.5 \mathrm{~g} /$ ha post eme.(20 DAS) & 1.01 & 2.04 & 3.10 & 3.13 & 3.12 \\
\hline $\mathrm{T}_{5}$ & Chlorimuron ethyl + Fenoxaprop-ethyl, $9.37 \mathrm{~g} / \mathrm{ha}+67.5 \mathrm{~g} / \mathrm{ha}$, post eme. & 1.01 & 1.80 & 2.91 & 2.93 & 2.90 \\
\hline $\mathrm{T}_{6}$ & Quizalafop-p-ethyl 5\% EC, 50 g/ha, post eme. (15 DAS) & 0.41 & 1.29 & 1.87 & 1.87 & 1.88 \\
\hline $\mathrm{T}_{7}$ & Imazethapyr 5\% EC, $50 \mathrm{~g} / \mathrm{ha}$, post eme. (25 DAS) & 0.37 & 1.15 & 1.72 & 1.72 & 1.72 \\
\hline $\mathrm{T}_{8}$ & Control (unweeded) & 0.33 & 0.91 & 1.31 & 1.33 & 1.34 \\
\hline $\mathrm{T}_{9}$ & Weed free & 1.21 & 2.11 & 3.28 & 3.38 & 3.38 \\
\hline & SEm & 0.14 & 0.11 & 0.18 & 0.21 & 0.20 \\
\hline & $\mathrm{CD}$ at $5 \%$ & 0.42 & 0.34 & 0.54 & 0.62 & 0.58 \\
\hline
\end{tabular}

\section{Dry weight of soybean/plant}

Data showed that the dry weight per plant gradually increased with the age of the crop till maturity. The rate of dry matter accumulation was maximum between 60-75 and 75 DAS to harvest and thus followed a normal growth pattern. At the age of 45 DAS also, the dry matter accumulation per plant showed significant effects.

Treatment $\mathrm{T}_{9}$ (weed free) had highest values $(20.60 \mathrm{~g}$ ) with respect to dry weight/plant compared to all the treatments at all growth stages, suggesting that the weed free situation improves the quantity the biomass of the crop. However, this treatment $\left(\mathrm{T}_{9}\right)$ was statistically at par with $\mathrm{T}_{4}$, fenoxaprop-pethyl (19.70) at harvest where as minimum dry weight (13.20 g) was recorded in $\mathrm{T}_{8}$ (control) at harvest which was almost at par with $\mathrm{T}_{7}$-Imazethapyr 5\% SL (14.90 g) and $\mathrm{T}_{6}$-quizalofopethyl $5 \% \mathrm{EC}(15.10 \mathrm{~g})$.

Table 3: Average dry weight of soybean plants as influenced by different treatments.

\begin{tabular}{|c|c|c|c|c|c|c|}
\hline \multirow{2}{*}{ Tr. No } & \multirow{2}{*}{ Treatments } & \multicolumn{5}{|c|}{ Dry weight of soybean plant (g) } \\
\hline & & 30 DAS & 45 DAS & 60 DAS & 75 DAS & At harvest \\
\hline $\mathrm{T}_{1}$ & Alachlor $50 \mathrm{EC}, 2.0 \mathrm{~kg} / \mathrm{ha}$ (Pre.eme.) & 2.67 & 6.85 & 11.10 & 12.12 & 18.10 \\
\hline $\mathrm{T}_{2}$ & Pendimethalin 30 EC, 750 g/ha (Pre.eme.) & 2.71 & 6.61 & 10.60 & 12.40 & 17.30 \\
\hline $\mathrm{T}_{3}$ & Chlorimuron-ethyl 25\% WP, $9.37 \mathrm{~g} / \mathrm{ha}$, post eme. (20 DAS) & 3.64 & 7.10 & 11.90 & 15.10 & 18.30 \\
\hline $\mathrm{T}_{4}$ & Fenoxaprop-p-ethyl 9\% EC, $67.5 \mathrm{~g} / \mathrm{ha}$ post eme.(20 DAS) & 3.80 & 7.81 & 13.20 & 16.00 & 19.70 \\
\hline $\mathrm{T}_{5}$ & Chlorimuron ethyl + Fenoxaprop-ethyl, $9.37 \mathrm{~g} / \mathrm{ha}+67.5 \mathrm{~g} / \mathrm{ha}$, post eme. & 3.71 & 7.31 & 12.00 & 15.90 & 19.30 \\
\hline $\mathrm{T}_{6}$ & Quizalafop-p-ethyl 5\% EC, $50 \mathrm{~g} / \mathrm{ha}$, post eme. (15 DAS) & 1.98 & 6.31 & 9.10 & 12.20 & 15.10 \\
\hline $\mathrm{T}_{7}$ & Imazethapyr 5\% EC, $50 \mathrm{~g} / \mathrm{ha}$, post eme. (25 DAS) & 1.95 & 6.01 & 9.33 & 11.80 & 14.90 \\
\hline $\mathrm{T}_{8}$ & Control (unweeded) & 1.82 & 5.61 & 8.21 & 10.10 & 13.20 \\
\hline $\mathrm{T}_{9}$ & Weed free & 3.93 & 7.97 & 13.90 & 17.30 & 20.60 \\
\hline & SEm & 0.33 & 0.33 & 0.73 & 0.92 & 0.87 \\
\hline & $\mathrm{CD}$ at $5 \%$ & 0.99 & 0.96 & 2.12 & 2.69 & 2.54 \\
\hline
\end{tabular}

\section{Leaf area index}

The total area accumulated by the soybean plant per unit of the ground area in which the crop was grown was recorded under each treatment at 30, 45, 60 and 75 DAS. The leaf area index was significantly affected by different treatments at all the periods of growth that is 30,60 and 75 DAS. The highest 
values (8.25) of LAI recorded in the treatment $\mathrm{T}_{9}$ (weed free plot) at all the growth stages, which was significantly superior to the LAI recorded under each treatment at 30 DAS except
$\mathrm{T}_{4}$ and $\mathrm{T}_{5}$ at $45 \mathrm{DAS}, \mathrm{T}_{3}$, at 60 and 75 DAS while minimum LAI recorded under $\mathrm{T}_{8}$ (control) at all the stages of growth.

Table 4: Leaf area index as influenced by different treatments

\begin{tabular}{|c|c|c|c|c|c|}
\hline \multirow{2}{*}{ Tr. No } & \multirow{2}{*}{ Treatments } & \multicolumn{4}{|c|}{ Leaf area index } \\
\hline & & 30 DAS & $45 \mathrm{DAS}$ & 60 DAS & 75 DAS \\
\hline $\mathrm{T}_{1}$ & Alachlor $50 \mathrm{EC}, 2.0 \mathrm{~kg} / \mathrm{ha}$ (Pre.eme.) & 3.16 & 3.77 & 4.54 & 6.43 \\
\hline $\mathrm{T}_{2}$ & Pendimethalin 30 EC, $750 \mathrm{~g} / \mathrm{ha}$ (Pre.eme.) & 3.10 & 3.80 & 4.60 & 6.30 \\
\hline $\mathrm{T}_{3}$ & Chlorimuron-ethyl 25\% WP, $9.37 \mathrm{~g} / \mathrm{ha}$, post eme. (20 DAS) & 3.15 & 4.10 & 5.05 & 7.10 \\
\hline $\mathrm{T}_{4}$ & Fenoxaprop-p-ethyl 9\% EC, $67.5 \mathrm{~g} / \mathrm{ha}$ post eme.(20 DAS) & 3.40 & 4.48 & 5.51 & 7.65 \\
\hline $\mathrm{T}_{5}$ & Chlorimuron ethyl + Fenoxaprop-ethyl, $9.37 \mathrm{~g} / \mathrm{ha}+67.5 \mathrm{~g} / \mathrm{ha}$, post eme. & 3.70 & 4.40 & 5.35 & 7.42 \\
\hline $\mathrm{T}_{6}$ & Quizalafop-p-ethyl 5\% EC, $50 \mathrm{~g} / \mathrm{ha}$, post eme. (15 DAS) & 2.92 & 3.55 & 4.21 & 5.85 \\
\hline $\mathrm{T}_{7}$ & Imazethapyr 5\% EC, $50 \mathrm{~g} / \mathrm{ha}$, post eme. (25 DAS) & 2.50 & 3.25 & 3.80 & 5.35 \\
\hline $\mathrm{T}_{8}$ & Control (unweeded) & 2.18 & 2.79 & 3.61 & 5.21 \\
\hline $\mathrm{T}_{9}$ & Weed free & 3.19 & 4.79 & 6.04 & 8.25 \\
\hline & SEm & 0.16 & 0.19 & 0.35 & 0.41 \\
\hline & CD at $5 \%$ & 0.45 & 0.57 & 1.02 & 1.19 \\
\hline
\end{tabular}

\section{Yield parameters}

\section{Number of pods/plant}

The increase in grain yield of soybean crop is determined by the bearing of number of pods. The number of pods per plant directly affects the number of grains per plant and ultimately the final grain yield of the crop. The highest number of pods (30.90) per plant was recorded under treatment $\mathrm{T}_{9}$ (weed free plot) followed by 27.60 pods per plant in the treatment $\mathrm{T} 4$, fenoxaprop-p-ethyl 9\% EC when applied as post-emergence treatment at 20 DAS. Among the different chemical herbicides used, the next treatment was $\mathrm{T}_{3}$-chilorimuron-ethyl $25 \% \mathrm{WP}$, which recorded 26.60 number of pods/plant.

\section{Seed index}

Seed index is considered to be an important character, which contributes towards the yield of the crop. The highest 100 seed weight $(11.10 \mathrm{~g})$ was recorded under treatment $\mathrm{T}_{9}$, weed free plot followed by $\mathrm{T}_{4}$, fenoxaprop-p-ethyl, which gave the value of $11.00 \mathrm{~g}$. The lowest seed index (9.20) was recorded under treatment $\mathrm{T}_{8}$, control. However, the 100 seed weight under all the treatments of chemical herbicides was found quite close to each other as compared to $11.10 \mathrm{~g}$ under treatment $\mathrm{T}_{9}$-weed free plot. Thus, the treatment $\mathrm{T}_{9}$, the weed free plot and use of fenoxaprop-p-ethyl at 20 DAS proved effective.

Table 5: Number of pods/plant and seed index ( $\mathrm{g}$ ) as influenced by different treatments

\begin{tabular}{|c|c|c|c|}
\hline Tr. No. & Treatments & Pods/ plant & Seed index \\
\hline $\mathrm{T}_{1}$ & Alachlor 50 EC, $2.0 \mathrm{~kg} / \mathrm{ha}$ (Pre.eme.) & 24.80 & 10.50 \\
\hline $\mathrm{T}_{2}$ & Pendimethalin 30 EC, $750 \mathrm{~g} / \mathrm{ha}$ (Pre.eme.) & 24.80 & 6.30 \\
\hline $\mathrm{T}_{3}$ & Chlorimuron-ethyl 25\% WP, 9.37 g/ha, post eme. (20 DAS) & 26.60 & 10.60 \\
\hline $\mathrm{T}_{4}$ & Fenoxaprop-p-ethyl 9\% EC, 67.5 g/ha post eme.(20 DAS) & 27.60 & 11.00 \\
\hline $\mathrm{T}_{5}$ & Chlorimuron ethyl + Fenoxaprop-ethyl, 9.37 g/ha + 67.5 g/ha, post eme. & 27.70 & 10.60 \\
\hline $\mathrm{T}_{6}$ & Quizalafop-p-ethyl 5\% EC, 50 g/ha, post eme. (15 DAS) & 22.90 & 9.73 \\
\hline $\mathrm{T}_{7}$ & Imazethapyr 5\% EC, 50 g/ha, post eme. (25 DAS) & 20.00 & 9.40 \\
\hline $\mathrm{T}_{8}$ & Control (unweeded) & 17.40 & 9.20 \\
\hline $\mathrm{T}_{9}$ & Weed free & 30.90 & 11.10 \\
\hline & SEm & 1.53 & 0.28 \\
\hline & CD at 5\% & 4.48 & 0.83 \\
\hline
\end{tabular}

\section{Grain yield (q/ha)}

The highest grain yield of $14.33 \mathrm{q} / \mathrm{ha}$ was recorded under treatment $\mathrm{T}_{9}$-weed free plot followed by $14.0 \mathrm{q} / \mathrm{ha}$ under treatment $\mathrm{T}_{4}$-fenoxaprop-p-ethyl $9 \%$ EC while lowest grain yield of $9.14 \mathrm{q} /$ ha was obtained under treatment $\mathrm{T}_{8}$ (control). Treatment $\mathrm{T}_{3}$ and $\mathrm{T}_{5}$ with grain yield of 13.34 and $13.62 \mathrm{q}$ per hectare were recorded at par with each other. Thus all the herbicidal treatments as well as treatment $\mathrm{T}_{9}$-weed free plot were recorded significantly superior to control $\left(\mathrm{T}_{8}\right)$ under the assessed herbicidal treatments from gain yield/ha point of view.

\section{Stover yield (q/ha)}

The highest amount of stover yield (15.52 q/ha) was recorded under $\mathrm{T}_{9}$-weed free plot followed by $14.73 \mathrm{q} / \mathrm{ha}$ under treatment $\mathrm{T}_{4}$. Higher quantity of stover production naturally resulted in lower grain yield of $9.14 \mathrm{q} / \mathrm{ha}$ due to weedy condition of this treatment. $\mathrm{T}_{1}, \mathrm{~T}_{5}$ and $\mathrm{T}_{7}$ were found almost at par with each other but the $\mathrm{T}_{9}$-weed free plot was significantly superior to these treatments as far as stover yield/ha is concerned while lowest stover yield of $11.38 \mathrm{q} / \mathrm{ha}$ was recorded under $\mathrm{T}_{8}$-weed check.

\section{Harvest index (\%)}

The maximum harvest index of $49.77 \%$ was recorded under treatment $T_{5}$, in which there was a larger gap between the grain yield and stover yield per hectare. Harvest index of $48.19 \%$ was recorded in treatment $\mathrm{T}_{9}$ (weed free plot) which was almost at par with harvest index under many other treatments. The harvest index values of the treatments of chemical herbicides ranged between $49.77 \%$ and $46.87 \%$. The lowest harvest index $(43.21 \%)$ was recorded in control plot (weedy condition). 
Table 6: Mean grain yield, stover yield and harvest index as influenced by different treatments

\begin{tabular}{|c|c|c|c|c|}
\hline \multirow{2}{*}{ Tr No. } & \multirow{2}{*}{ Treatments } & \multicolumn{2}{c|}{ Yield (q/ha) } & Harvest index \\
& & Grain & Stover & $(\%)$ \\
\hline $\mathrm{T}_{1}$ & Alachlor 50 EC, 2.0 kg/ha (Pre.eme.) & 13.14 & 14.05 & 48.31 \\
\hline $\mathrm{T}_{2}$ & Pendimethalin 30 EC, 750 g/ha (Pre.eme.) & 12.86 & 14.16 & 47.59 \\
\hline $\mathrm{T}_{3}$ & Chlorimuron-ethyl 25\% WP, 9.37 g/ha, post eme. (20 DAS) & 13.34 & 13.95 & 48.86 \\
\hline $\mathrm{T}_{4}$ & Fenoxaprop-p-ethyl 9\% EC, 67.5 g/ha post eme.(20 DAS) & 14.00 & 14.73 & 48.83 \\
\hline $\mathrm{T}_{5}$ & Chlorimuron ethyl + Fenoxaprop-ethyl, 9.37 g/ha + 67.5 g/ha, post eme. & 13.62 & 13.65 & 49.77 \\
\hline $\mathrm{T}_{6}$ & Quizalafop-p-ethyl 5\% EC, 50 g/ha, post eme. (15 DAS) & 12.86 & 14.58 & 46.87 \\
\hline $\mathrm{T}_{7}$ & Imazethapyr 5\% EC, 50 g/ha, post eme. (25 DAS) & 12.38 & 13.91 & 47.17 \\
\hline $\mathrm{T}_{8}$ & Control (unweeded) & 9.14 & 11.38 & 43.21 \\
\hline $\mathrm{T}_{9}$ & Weed free & 14.33 & 15.52 & 48.19 \\
\hline & SEm & 0.49 & 0.57 & 1.28 \\
\hline & CD at 5\% & 1.45 & 1.66 & 3.72 \\
\hline
\end{tabular}

\section{Economic evaluation of treatments}

The highest net return (Rs. 32796/ha) was obtained under the treatment $\mathrm{T}_{9}$ (weed free situation) closely followed by $\mathrm{T}_{4}$ fenoxaprop-p-ethyl 9\% EC (Rs. 32359/ha) while the lowest net return (Rs. 18284/ha) was received under the treatment $\mathrm{T}_{8}$ (control). The highest benefit:cost ratio (2.30) was obtained under the treatment $\mathrm{T}_{4}$-Fenoxaprop-p-ethyl 9\% EC closely followed by $\mathrm{T}_{3}$-Chlolrimuron-ethyl $25 \% \mathrm{WP}(2.29)$ and $\mathrm{T}_{9}$ (weed free situation) (2.20) while the lowest benefit:cost ratio (1.45) was received under the treatment $\mathrm{T}_{8}$ (control).

Treatments $\mathrm{T}_{1}, \mathrm{~T}_{5}$ and $\mathrm{T}_{2}$ were recorded the $\mathrm{B}: \mathrm{C}$ ratio 2.10 , 2.08 and 2.02 which were at par to $\mathrm{T}_{4}$-fenoxaprop-ethyl $9 \%$ $\mathrm{EC}$ and $\mathrm{T}_{9}$ (weed free situation). Thus, the chemical treatment $\mathrm{T}_{4}$-fenoxaprop-ethyl 9\% EC and weed free situation treatment were found to be economically more valuable than others.

Table 7: Economic evaluation of treatments

\begin{tabular}{|c|c|c|c|c|c|c|c|}
\hline \multirow{2}{*}{ Tr. No } & \multirow{2}{*}{ Treatments } & \multicolumn{2}{|c|}{ Expenditure (Rs/ha) } & \multirow{2}{*}{ Tatal cost $(\mathrm{Rs} / \mathrm{ha})$} & \multicolumn{2}{|c|}{ Income (Rs/ha } & \multirow{2}{*}{ Cost: benefit ratio } \\
\hline & & Common & Extra & & Gross & Net & \\
\hline $\mathrm{T}_{1}$ & Alachlor $50 \mathrm{EC}$ & 12550 & 1570 & 14120 & 43635 & 29565 & $1: 2.10$ \\
\hline $\mathrm{T}_{2}$ & Pendimethalin $30 \mathrm{EC}$ & 12550 & 1600 & 14150 & 42828 & 28678 & $1: 2.02$ \\
\hline $\mathrm{T}_{3}$ & Chlolrimuron-ethyl 25\% WP & 12550 & 900 & 13450 & 44205 & 30805 & $1: 2.29$ \\
\hline $\mathrm{T}_{4}$ & Fenoxaprop-p-ethyl 9\% EC & 12550 & 1510 & 14060 & 46419 & 32359 & $1: 2.30$ \\
\hline \begin{tabular}{l|l}
$T_{5}$ & \\
\end{tabular} & Chlorimuron ethyl 25\% WP + Fenoxaprop-ethyl 9\% EC & 12550 & 2025 & 14575 & 44955 & 30380 & $1: 2.08$ \\
\hline $\mathrm{T}_{6}$ & Quizalofop-ethy 5\% EC & 12550 & 2100 & 14650 & 28304 & 13654 & 1:0.93 \\
\hline
\end{tabular}

The sale rate for soybean grain and stover were Rs. 3000/q and Rs.300/q, respectively.

\section{References}

1. Anonymous. Soybean Processors Association of India, SOPA Souvenir. All India Conversation of Oilseed and Oil Trade and Industries, 2014, 15p.

2. Bhan M, Kewat ML. Activity and persistence of pendimethalin applied pre- emergence to soybean in Vertisol, Ann. Agri. Res., New Series. 2003; 24(4):978982.

3. Halvankar GB, Varghese P, Taware SP, Raut VM. Effect of herbicide on weed dynamics and yield of soybean (Glycine $\max (\mathrm{L})$ Merrill). J. Maha. agril. Univ. 2005; 30(1):35-37.

4. Chetan F, Cornel C, Rusu T, Simon A. Determining influence on the cultivation technology on weeds and soybean production. Production Environment. 2015; 8:211- 215 .

5. Dwivedi RK, Pandre NK, Ahirwar MK. Integrated Weed Management in Soybean through Front Line Demonstration in Farmer's Field. International Journal of Current Microbiology and Applied Sciences. 2019; 8(11):880-883.

6. Jackson ML. Soil chemical analysis Pub. Prentice Hall of India Pvt. Ltd. New Delhi, 1967.

7. Kheriya A, Jha AK, Dubey J. Effect of Chemical Weed Control on Weed Flora and Yield of Soybean. Advances in Life Sciences. 2016; 5(16).
8. Kulal DA, Dhaigude GS, Adat SS. Evaluation of efficacy of post - emergence herbicides for weed control in soybean under Marathwada region. International Journal of Agricultural Sciences. 2017; 13(1):53-55.

9. Olsen SR, Cole CV, Watanabe FS, Dean LA. Estimation of available Phosphorus in soils by extraction with sodium bicarbonate. U.S.D.A. Circ., 1954, 939.

10. Patel A, Spare N, Malgaya G. Bio-Efficacy of Post Emergence Herbicides against Weed Control in Soybean. International Journal of Current Microbiology and Applied Sciences. 2019; 8(4):1964-1974.

11. Patil AS, Bhavsar MS, Deore PS, Raut DM. Effect of Integrated Weed Management on Weed Dynamics of Soybean [Glycine max (L.) Merill] under Junagadh, India. International Journal of Current Microbiology and Applied Sciences. 2018; 7(1):1110-1115.

12. Piper C. Soil and plant analysis. University of Adelaide, Australia, 1950.

13. Prachand S, Kubde KJ, Bankar S. Effect of chemical weed control on weed parameters, growth, yield attributes, yield and economics in Soybean (Glycine max). American Eurasian Journal Agricultural and Environment Science. 2014; 14(8):698-701.

14. Sandil MK, Sharma JK, Sanodiya P, Pandey A. Bioefficacy on tank mixed Propaquizafop and Imazethapyr against weeds in soybean. Indian Journal of Weed Science. 2015; 47(2):158-162.

15. Sharma GD, Sharma JJ, Sonisood. Evaluation of alachlor, metachlor and pendimethanlin for weed control in Rajmash (Phaseolus valgaris L.) in cold desert of 
North Western Himalayas. Indian J. Weed Sci. 2004; 36(3-4):287-289.

16. Subbhiah BV, Asija GL. A rapid method for estimation of nitrogen in soil. Current Science. 1956; 25:259-250.

17. Thakre SS, Deshmukh JP, Shingrup PV, Pawar PM, Ghlop AN. Efficacy of different new herbicides against weed flora in soybean (Glycine max (L.) Merrill). Plant Archives. 2015; 15(1):217-220.

18. Tiwari JP, Kurchania SP, Paradkar NR, Bhalla SP. Varietal susceptibility and weed control efficiency of fluazifop-p-butyl in soybean (Glycine max). Indian J. agric. Sci. 1997; 67(4):147-149.

19. Vyas MD, Singh S, Singh PP. Weed management in soybean (Glycine $\max$ (L.) Merrill). Annals of Plant Protection Sci. 2000; 8(1):76-78.

20. Walkley A, Black CA. An examination of degtjareff for determining soil organic matter and a proposed modification of the chromic acid titration method. Soil Science. 1934; 37:29-38. 